\title{
SECRETS OF THE ACADEMY: \\ THE DRIVERS OF UNIVERSITY ENDOWMENT SUCCESS
}

\author{
Josh Lerner \\ Antoinette Schoar \\ Jialan Wang \\ Working Paper 14341 \\ http://www.nber.org/papers/w14341 \\ NATIONAL BUREAU OF ECONOMIC RESEARCH \\ 1050 Massachusetts Avenue \\ Cambridge, MA 02138 \\ September 2008
}

The views expressed herein are those of the author(s) and do not necessarily reflect the views of the National Bureau of Economic Research.

NBER working papers are circulated for discussion and comment purposes. They have not been peerreviewed or been subject to the review by the NBER Board of Directors that accompanies official NBER publications.

(C) 2008 by Josh Lerner, Antoinette Schoar, and Jialan Wang. All rights reserved. Short sections of text, not to exceed two paragraphs, may be quoted without explicit permission provided that full credit, including $(\odot$ notice, is given to the source. 
Secrets of the Academy: The Drivers of University Endowment Success

Josh Lerner, Antoinette Schoar, and Jialan Wang

NBER Working Paper No. 14341

September 2008

JEL No. G11,L3

\begin{abstract}
In recent years, university endowments have received much attention for their spectacular returns and innovative investment strategies, but few papers have examined trends in the endowment sector at large. In this paper, we analyze a sample of 1,300 educational endowments between 1992 and 2005. A striking phenomenon emerges of the "rich getting richer", a dramatic widening of the size gap between the largest endowments, led by the Ivy League, and the average endowment. Growth in endowment size has been driven largely by high investment returns, which are in turn related to the quality of the student body and the use of alternative assets. Elite endowments seem to benefit not only from economies of scale in investment management, but genuine skill and expertise in choosing the right investments at the right times.
\end{abstract}

Josh Lerner

Harvard Business School

Rock Center 214

Boston, MA 02163

and NBER

jlerner@hbs.edu

Antoinette Schoar

Sloan School of Management

50 Memorial Drive, E52-455

Cambridge, MA 02142

and NBER

aschoar@mit.edu
Jialan Wang

Sloan School of Management

Massachusetts Institute of Technology

Cambridge, Massachusetts

jialanw@mit.edu 
University endowments are important and interesting institutions both in the investing community and society at large. First, they play a role in maintaining the academic excellence of many universities which rely heavily on income from their endowments. In recent years, wellheeled institutions such as Harvard and Princeton have used their deep pockets to increase admissions and reduce effective tuition rates, broadening access to elite education (Hoover, 2007; Farrell, 2007). In contrast, poor finances can undermine a school's ability to provide academic services all together. In a dramatic recent case, the 150 year-old liberal arts institution Antioch College announced in 2007 that it would need to close its doors in 2008 due largely to financial woes. While similar institutions such as Reed College, Oberlin College, and Kenyon College had endowments of over \$100 million, Antioch’s endowment of only \$36 million engendered financial insecurity, which contributed to decaying facilities and a declining student base (Carlson, 2007). Although Antioch forestalled closure thanks to an emergency fund-raising drive, its financial future remains uncertain. Another example comes from the University of Rochester, which in the early 1970s had had the third largest endowment in the country, after Harvard and the University of Texas. However, its endowment suffered poor returns in the subsequent two decades, and fell to the 25th largest by 1995. Among its poor choices were heavy allocations of its public equity portfolio to local companies such as Kodak and Xerox, which suffered substantial reversals during the period (Shea, 1995; "Manifold," 1974). Largely as a result of its underperforming endowment, Rochester dramatically downsized its faculty and programs in the mid-1990s.

Endowments have also received much attention recently for their superior investment returns compared with other institutional investors (Lerner, Schoar, and Wongsungwai, 2007). In this study, we document the trends in college and university endowment returns and investments 
in the United States between 1992 and 2005. Such endowments overall have performed well over in this time period, with a median growth rate of 7.4 percent per year and median return of 6.9 percent, according to our data on 1300 schools. This sector has been dominated both in size and performance by the endowments of elite universities such as the Ivy League schools. The top 20 endowments grew more than 9 percent annually on a real basis between 1992 and 2005. As of 2007, the two largest endowments, belonging to Harvard and Yale, have grown to \$35 billion and $\$ 22$ billion in size, respectively. These results suggest an increasing skewness of endowment sizes, where the rich universities are getting richer while the rest of the schools are falling behind.

Much of the growth in endowment size has been driven by investment performance. As we will shown in the paper,, the top endowments posted impressive returns in 2005, averaging a net real return of 12.3 percent compared to 4.4 percent posted by the Standard \& Poor's 500 index in the same year. Indeed, over the past two decades, a significant number of college and university endowments have been in the top percentile of performance among all institutional investors. Based on rankings of performance of large defined benefit plans from financial research firm SEI, 5 percent of college and university endowments exceeded the top percentile return for corporate pension funds between 1996 and 2005. We investigate the underlying drivers of these high returns and show that performance is related to the size of endowment, the quality of the student body, and the use of alternative investments.

Our results also suggest caution to investors seeking to reap similar rewards by copying the investment strategies of top endowments. Across endowments, institutional characteristics such as endowment size and admissions selectivity are better predictors of success than the allocation to risky asset classes. Moreover, top endowments seem to possess superior asset 
selection ability beyond their strategies for allocating funds to certain asset classes. While we cannot pinpoint the channel through which more selective schools make better investments, qualitative evidence suggests that these endowments benefit from superior investment committees (the bodies charged with providing oversight and guidance to the endowment managers), more highly-skilled investment managers, and the broader knowledge bases and social networks of the schools themselves. Furthermore, while investments in risky asset classes such as alternative assets have on average been very successful, there have also been some dramatic losses, like the $\$ 350$ million investment loss that Harvard recently experienced in Sowood Capital Management (Karmin and Zuckerman, 2007). Thus, our findings do not imply that ordinary investors could achieve similar results by mimicking the strategies of top endowments. Indeed, the same strategies that have worked so well for the endowments in the past two decades may not do so in the future.

Facts about Endowments

While university endowments have attracted an increasing amount of publicity in recent years for their explosive growth and spectacular performance, few studies have examined systematic trends in the endowment sector as a whole. ${ }^{1}$ For the most comprehensive data on endowment returns, asset allocations, and returns, we turn to annual surveys conducted by the National Association of College and University Business Officers (NACUBO). Membership in NACUBO currently includes 2,500 public and private institutions, and the schools in our sample represent about a quarter of the student population in four-year institutions nationwide. On an annual basis since the 1970s, NACUBO has conducted voluntary surveys of member schools

\footnotetext{
${ }^{1}$ A contemporaneous paper using similar data is Brown et al. (2007).
} 
regarding endowment returns and investment characteristics. Participation in this survey has increased steadily year by year, and we focus our analysis on the period from 1992 to 2005, over which data from nearly 1,300 schools are available. Due to data availability, we use data from 1993 to 2005 when analyzing aggregate returns and allocations by asset class. We further restrict the sample to 2002 to 2005 when looking at asset class returns and some institutional characteristics. We supplement the NACUBO surveys with data from the College Board, a nonprofit organization that administers the SAT and other educational assessments and which collects information on each school's student population, including total number of enrolled students and the percentile scores on the SAT.

In general, the schools included in the NACUBO surveys tend to be larger, more selective, and more likely to be private than the average school: our endowment data covers about 45 percent of the private schools in the College Board sample, but only 18 percent of the public schools. In particular, the NACUBO data has much better coverage of small private schools than of small public schools. Despite this sample selection issue, the results in this paper are qualitatively similar when we assume a similar coverage ratio of private and public endowments by dropping the smallest private endowments from the sample.

Table 1 presents some summary statistics for our data, presenting snapshots of the overall sample and public, private, and Ivy League schools in 1993 and 2005. In particular, throughout this study we contrast Ivy League and non-Ivy League schools. ${ }^{2}$ Because the Ivy League has historically been a focal point for public opinion on both higher education and endowment investment, we present separate statistics for these schools to identify differences between the

\footnotetext{
${ }^{2}$ The Ivy League is an old nickname for a set of schools that formed an athletic association in 1954, which includes Brown University, Columbia University, Cornell University, Dartmouth College, Harvard University, University of Pennsylvania, Princeton University, and Yale University.
} 
endowments of these elite institutions and the typical endowment. To avoid overlap, we exclude Ivy League schools from the sample of private schools in the table.

Overall, private schools comprise 63 percent of our sample, and public schools comprise 37 percent. Despite large differences in the size of their student populations, endowment characteristics differed only moderately between public and private schools. Private schools have tended to invest more aggressively in alternative assets (like hedge funds, private equity, and commodities), and they have achieved slightly higher overall returns and asset class returns. While investment returns were similar for public and private schools, endowments for public schools grew 4 percent more per year than private schools between 1993 and 2005, suggesting a larger role for donations (or government transfers) in public endowments.

Despite higher endowment growth rates, public schools have had much lower endowment values per student than private schools. They have also experienced higher tuition increases, with median annual tuition hikes of 3.8 percent versus 2.5 percent for private schools. For example, while Texas A\&M University has maintained one of the largest educational endowments in the nation throughout the sample period (see Table 2), its endowment amounted to less than $\$ 60,000$ per student in 1993 , and tuition grew by over 16 percent per year between 1993 and 2005. In contrast, Columbia University's endowment was of similar size but represented nearly $\$ 560,000$ per student in 1993, and tuition grew by only 2.2 percent over the same period.

While the median public and median private school endowments were roughly the same size in both 1993 and 2005, the median endowment in the Ivy League dwarfed the typical endowment by orders of magnitude (all except Dartmouth and Brown are listed among the 20 largest endowments in Table 2). Furthermore, the gulf had widened dramatically: while the 
median Ivy League endowment was about 40 times larger than the median public endowment in 1993, this multiple was up to 70 times by 2005. The same pattern emerges when considering we divide endowments by the size of their investment pools or by the SAT scores of the student body. Hence, we consistently find a "rich get richer" phenomenon among educational endowments.

These changes in endowment size come from three major sources: investment returns, donations, and spending. While our data provide very limited information on donations, Table 1 indicates that spending rates out of endowments differ only slightly across institutions. However, investment returns vary dramatically and are a major source of differences in endowment growth. In the next section, we will explore the drivers of investment performance across endowments.

Trends in Endowment Returns

As shown in Table 1, endowments have generally enjoyed healthy returns between 1993 and 2005, but they also display considerable heterogeneity. Do schools with different characteristics show consistent differences in returns? Figure 1 plots the patterns in excess returns above the Standard \& Poor's 500 for several subsets of schools in each year of the sample. As shown in Figure 1, the Ivy League schools realized dramatically higher excess returns compared to the rest of the endowments, outperforming the overall median by more than 3 percent per year. Note that in contrast to Table 1, the figures are derived from data which excludes schools reporting less than 10 years of data between 1992 and 2005. This difference is particularly striking in 2000, when Ivy League schools outperformed the other universities by 14 
percent. In contrast, private universities excluding the Ivy League performed almost identically to the overall average.

Large schools and those with high student SAT scores also performed very similarly between 1992 and 2005, with returns which generally exceeded the overall average. As shown in Figure 1, the median schools in the top quartiles by SAT score and by endowment size outperformed the overall average by 1.3 percent per year in this period. In unreported results which sort schools by these two variables in 1992, a 10-percentile increase in either variable is associated with higher returns in every year between 1992 and 2005 across the entire range of the two variables. Hence, although endowment size and student SAT score are somewhat correlated (with a correlation coefficient of 0.4 ), our analysis suggests that both variables correlate positively and independently with endowment performance.

Endowment size may play a role because of economies of scale in endowment management. Small endowments are often managed by general university financial officers who may not be trained in sophisticated asset management, while the largest endowments are able to hire a mixture of skilled inside and outside managers with specific expertise for their investment goals and asset compositions. ${ }^{3}$ While the SAT scores of a university's students are unlikely to directly affect investment performance, average SAT score may be a proxy for the skill of the university administration, the wealth and connections of the alumni network, and the prestige of the university brand, all of which could affect endowment management over and above the role of endowment size. These factors may have played a role in the success of Williams College, which achieved an inflation-adjusted return of 11.7 percent per year between 1992 and 2005 with

\footnotetext{
${ }^{3}$ The choice between relying on outside managers and internal staff pose many interesting issues, which we do not analyze here, due to a lack of time-series data in the NACUBO data-set. The Yale and (traditionally) the Harvard endowments provide illustrations of organizations which have respectively followed these two strategies with considerable success.
} 
an $\$ 1.3$ billion endowment in 2005 and $75^{\text {th }}$-percentile SAT score of 750, beating out schools such as University of Pittsburgh which had larger endowments but significantly lower SAT scores. Without more detailed data, however, we cannot identify the specific channels through which size and SAT score affect endowment performance, so useful insights could be gained from future research into these institutional characteristics.

Finally, Figure 1 also suggests a remarkable persistence in the performance of endowments year after year. As shown in the figure, top endowments such as those of the Ivy League (and more generally, large endowments and those of high-SAT schools) tend to post consistently above-average returns. Upon further investigation, we find that persistence also holds true at the low end: endowments which perform worse than average continue to do poorly year after year. These results corroborate the findings in a recent paper by Lerner, Schoar, and Wongsunwai (2007), which also reported persistence in returns at the institutional investor level. While that paper focused only on returns in private equity, it is striking that we find persistence of returns for educational endowments which invest across wide spectrum of asset classes, including those in highly efficient markets such as those for stocks and bonds. In the next section, we will take a closer look at the investment strategies adopted by educational endowments.

Asset Allocation and the Role of Alternative Assets

Much of endowment performance is achieved through allocation decisions between asset classes which have different risk and return characteristics. Specifically, we examine endowment investment across five major asset classes: equities, fixed income, real estate, 
alternatives (which includes hedge funds, commodities such as oil and timber, and private equity buyout and venture funds), and cash. While the 1970 and 1980s saw a gradual move by endowments away from fixed income securities and cash into equities, our sample period witnessed a shift away from equities and fixed income toward the sophisticated, often illiquid alternative assets. Figure 2 provides an overview of the allocation of university endowments by asset class between 1993 and 2005. The combined share of equities and fixed income fell from 83 percent in 1993 to 73 percent in 2005. At the same time, the share of alternatives rose from 11 to 21 percent, leaving the shares of real estate and cash holdings essentially constant.

While endowments overall have increased their allocations toward alternative assets, tremendous heterogeneity still exists in the share of the total endowment invested in alternatives. Figure 3 shows the median share of investments devoted to alternative investments among five subsets of endowments. As shown in the figure, schools with high SAT scores and large endowments began the shift toward alternative assets earlier than the typical school and have consistently placed a larger share of their assets in alternative investments.

The share of endowments at Ivy League schools devoted to alternative assets had been even bigger: they consistently invested twice as much into alternative assets than the median school (the medians for the Ivy League and the entire sample are 9.3 vs. 4.3 percent in 1993; 38 vs. 12 percent in 2005). The Yale endowment provides an extreme example: at the end of the 2006 fiscal year, the university's target allocation was to hold 69 percent of its portfolio in private equity, hedge funds, and real estate (Lerner, 2007). Thus, the endowments with the best performance have also allocated most aggressively toward alternative investments.

A natural conclusion from this evidence might be that endowments which are lagging ought to shift their allocations toward alternative assets. Some institutional investors around the 
world have reached this conclusion: for instance, the Kuwait Investment Fund decided to emulate Yale's allocation when shifting its investment strategy (Sender, 2007). However, we argue in this paper that simply mimicking the asset allocation strategies of the best endowments may not lead to the same stellar results.

One reason is that superior endowment performance may be due not just to asset class allocation, but also to selection of assets within each class. Although we cannot precisely determine the returns an arbitrary investor could achieve by passively following the allocation strategies of endowments, Table 3 presents aggregate comparisons between returns realized by endowments and benchmark returns from broad indices in the five major asset classes. While endowment returns roughly tracked benchmark returns between 1994 and 1999, between 2000 and 2005 all subsets of endowments consistently outperformed their benchmarks. This trend may indicate that endowments have become more skilled at selecting assets within asset classes over time. However, it may also result from the banner performance of riskier assets such as emerging-market equities, and alternative assets which have been recently favored by endowments--and these assets are not guaranteed to perform equally well in the future.

Overall, roughly 73 percent of endowment returns between 1994 and 2005 is accounted for by the benchmark asset class returns weighted by aggregate allocations to these classes. This value is about 77-78 percent for large endowments and the endowments of private schools and high-SAT schools. In contrast, benchmark returns account for only 66 percent of the returns of Ivy League schools, indicating that the top endowments do more than just correctly time investment in particular asset classes. The large role of expertise in the performance of top endowments should caution against naïve imitation of their allocation strategies. 
This warning is especially true for investments in alternative assets, where poor selection can have significant negative effects. Alternative assets vary considerably in their performance, and Table 3 indicates that Ivy League schools possess investment skills and options the average investor would probably be unable to match. More detailed analysis shows that schools which entered earlier into alternative assets (which tended to be those with larger endowments and higher SAT scores) achieved higher returns within this asset class, even after controlling for the percentage allocation to alternatives.

The perils faced by schools unfamiliar with alternative investments can be illustrated by the experience of Boston University. The school's administration established its own venture capital subsidiary; in contrast, most leading universities have done the bulk of their alternative investing through outside partnerships, rather than trying to undertake these activities directly. The fund invested in Seragen, a privately held biotechnology company founded in 1979 by scientists affiliated with Boston University. The result of this investment can be described based on Seragen's filings with the U.S. Securities and Exchange Commission. As part of the school's initial investment in 1987, it bought out the stakes of a number of independent venture capital investors, who had apparently concluded after a number of financing rounds that the firm's prospects were unattractive. Between 1987 and 1997, the school, investing alongside university officials and trustees, provided at least $\$ 107$ million dollars to the private firm. (By way of comparison, the school's entire endowment in the fiscal year in which it initiated this investment was \$142 million.) While the company succeeded in completing an initial public offering, it encountered a series of disappointments with its products. By late 1997, the University's equity stake was worth only about $\$ 4$ million. 
This pattern in which alternative investments provide high returns only to a few top endowments is consistent with previous analysis of the returns from private equity investments (Lerner, Schoar, and Wongsunwai, 2007). While the returns from private equity investments for the top 25 percent of the endowments in that sample far outperform those of any other class of investor, the other schools have relatively modest returns that are indistinguishable from those of average investors. In particular, the two most consistent correlates with private equity performance were the SAT scores of the student body and the rate of the alumni giving. Why might alternative investments perform better for some schools than others? Although we do not have detailed data to support our arguments here, the key factors are likely to be access, experience, and timing.

On the issue of access, many of the most successful private equity and hedge funds are essentially closed to new investors and have been so for many years. Thus, one important aspect of having been pioneers in alternative investments is that the Ivy League endowments enjoy a "seat at the table" in some of the most elite and desirable groups. An endowment just beginning an alternative investment program is unlikely to be able to access the top-tier or even the secondtier alternative funds. However, access cannot explain all of the superior returns of established endowments. In Lerner, Schoar, and Wongsunwai (2007), we found that top endowments even outperformed the rest of the investors when investing in undersubscribed funds, which suggests that those endowments were able to pick better funds even when all investors had access.

Much of success of alternative investment programs comes from experience: there is a great deal of disparity in the returns of individual managers within the asset class, placing a premium on manager selection (for instance, see the data in Yale, 2006). Furthermore, the long lags between the time when investments are made and when their success can be evaluated 
highlight the importance of experience in interpreting ambiguous data in making fund selection decisions. Hence, the experience gained by Ivy League schools which were among the first institutional investors to invest in alternatives may be a major factor in their continued success.

Finally, part of the success of alternative investments may be attributed to good timing. The past 25 years viewed as a whole have been a benign environment for many alternative funds. On the venture capital side, there has been extensive innovation and (until 2000) a robust market for new issues. Buyouts and hedge funds have benefited from the plethora of "value" investment opportunities in recent years and (until late 2007) the ready availability of debt finance on favorable terms. Whether these conditions will continue to hold in the decade to come remains to be seen.

\section{Compensation and Endowment Managers}

The skill and experience of investment managers appear to play a large role in the success of endowment investments, so differing abilities to attract and compensate talented managers may help explain the disparities in investment performance across endowments. Compensation of internal investment staff has proven intensely controversial at some schools. For example, two bond traders within Harvard's endowment group, David Mittelman and Maurice Samuels, each earned roughly \$34 million in 2003. After an outcry, their compensation was capped at \$25 million in 2004, a measure which did little to quiet the controversy (Seward, 2005). Although these numbers are high compared to the typical salaries of university staff, even the most highly-paid endowment personnel are compensated at a level that is generally far below what many of them would make at a hedge fund or other private organization. 
We examine the compensation of investment officers using data provided by GuideStar for schools in which endowment officers are one of the five highest-paid employees, between 1997 and $2004 .^{4}$ For a sample of 206 employee-year observations, we find compensation levels which are relatively modest by the standards of the private-sector financial industry. The mean compensation for a reported endowment officer was \$1.9 million. Furthermore, compensation levels seem to increase with excess returns as well as size and SAT scores, which from above are consistently correlated with performance. Among schools where compensation data are available, endowment officers in the top quarter of schools by excess return above the Standard \& Poor's 500 are paid $\$ 4.2$ million compared to $\$ 1.7$ million for those in the bottom quarter, those in the top quarter by endowment size are paid on average $\$ 5.3$ million compared to $\$ 100,000$ for the bottom quarter, and those in the top quarter of schools by SAT score are paid $\$ 6.1$ million on average compared to $\$ 130,000$. Are the top endowments more successful investors because they pay their endowment managers more, or does the fact that the pay them more reflect their success (and deep pockets)?

The association between the level of compensation and staff longevity seems weak at best, so the evidence here is only qualitative. For instance, a number of schools that have offered or discussed offering substantial incentive-based compensation to their staff, such as Harvard (Seward, 2005) and Stanford (Grant and Buckman, 2006), have also been among those hit by large-scale defections of investment staffs. Apparently, many schools with established, successful investment staffs have maintained them by emphasizing the non-pecuniary benefits that come from being a part of an academic community.

\footnotetext{
${ }^{4}$ One practical issue is how to recognize endowment staff in these reports. We define endowment staff as anyone whose title includes words such as "investment," "endowment," or "asset," or whose titles otherwise indicate direct involvement in endowment management. Another practical difficulty relates to matching the NACUBO and GuideStar data. For instance, in some cases, a multi-branch university will undertake a single 990 filing but fill out multiple responses to the NACUBO survey, or vice versa.
} 
Discussion and Conclusion

Many unanswered questions remain about university endowments. Three gaps in our understanding seem particularly interesting from an academic perspective and are especially relevant for those who run or oversee university endowments and other investment pools.

First, how does the way in which endowment offices are organized contribute to their returns? This question reflects a more fundamental gap in our understanding: While a voluminous literature exists on the pricing, risk, and returns of various types of assets, the organizational economics of investing, such as the challenges that institutional investors face in recruiting and rewarding investment professionals, remains poorly understood.

When we considered the top-performing university endowments and contrasted them with other institutional investors, several organizational features of the endowments stand out. First, the top-performing endowments have active investment committees, typically drawn from the ranks of alumni. These bodies typically see their role not as micro-managing the decisions of the investment staff, but rather in setting broad policy and serving as an informed sounding board. The contrast with public pension funds, where the bulk of the staff is drawn from rankand-file employees, is particularly stark. Second, the staff of successful academic endowments typically has considerable experience and has often worked together for many years. Finally, the staff of successful university and college endowments has an academic orientation, which leads to a process of periodic self-evaluation. Many of these funds occasionally stop to consider the processes that led them to make investments that proved particularly successful or problematic. They often engage in an active dialog with their peers. 
It would be useful to develop a better understanding of how these features affect success. In addition, given that the demand for investment talent is probably greater than it has ever been, it would be interesting to see whether these organizational features will be sustainable over time. The increased interest in alternative investments, and the demand for talent to lead the growing number of investment funds pursuing sophisticated strategies world-wide, are likely to increase the temptation for endowment managers to pursue their activities elsewhere. Whether the attraction of working for the good of an academic institution will be sufficient to retain top performers remains to be seen.

Second, will the strategies pursued by endowments remain viable going forward? The past two decades have been kind to alternative investment strategies pursued by many leading endowments, but it is unclear whether these patterns will hold into the future. The large endowments - and those of the Ivy League schools in particular-are considerably less correlated with the equity market and have greater exposure to the more volatile smaller stocks. These patterns highlight the extent to which these schools have been willing to pursue distinctive investment strategies.

Understanding the institutional qualities which allow some endowments to pursue unconventional investment strategies is particularly relevant because in a number of past episodes, schools pursued investment strategies that ultimately would have been successful, but were forced to abandon them when initial losses triggered media scrutiny and alumni complaints. To cite one vivid example, the Ford Foundation encouraged universities to increase investment in small-capitalization stocks in the late 1960s. A task force consisting of McGeorge Bundy, the foundation's president, and a number of distinguished academic leaders reviewed the historical returns data, and wrote: "It is our conclusion that past thinking by many endowment managers 
has been overly influenced by fear of another major crash. Although nobody can ever be certain what the future may bring, we do not think that a long-term policy founded on such fear can survive dispassionate analysis” (Advisory Committee, 1969).

If followed for the next several decades, this recommendation would have yielded very attractive returns, but it led to severe losses in the short-term for a number of university endowments that increased their allocation to small-capitalization stocks at the peak of the 1960s bull market. During much of the 1970s, returns were poor for stocks in general and smallcapitalization stocks in particular, leading to bitter criticism of endowment staffs by the media, alumni, and their investment committees. In the face of unrelenting criticism, many schools abandoned their small-cap strategies at exactly the wrong time. (Lerner (2007) discusses this report and its consequences at one school.) More recent examples along the same lines include endowment managers who attempted to hedge their exposure to venture capital in the late 1990s, but who were forced by their investment committees to abandon their positions right before the 2000 technology market collapse after experiencing several quarters where the hedges lost money. Perhaps further research into the dynamics and conflicts within organizations would help schools avoid repeating these episodes in the future.

A final concern relates to the challenges of imitation. The alternative investment markets on which successful endowments have relied are particularly vulnerable to influxes of capital (Gompers and Lerner, 2000; Kaplan and Schoar, 2005; Ljungqvist, Richardson, and Wolfenzon, 2007). A given sector often has a limited number of opportunities, so additional capital tends to be associated with the purchase of securities at higher prices and ultimately lower returns. This effect is particularly relevant because the strategies of the elite endowments are being scrutinized and imitated as never before. 
In the past, there was often a substantial lag between the time endowments first began investing in an asset class and when other institutions followed. For instance, many of the Ivy League schools began investing in venture capital in the early 1970s, but most corporate pensions did not follow until the 1980s and most public pensions did not follow until the 1990s. These lags have become much shorter. Within a couple of years of Harvard initiating a program to invest in forestland, for instance, many other institutions adopted similar initiatives. The same dynamics are at play at the individual fund level: an investment by an elite endowment into a fund can trigger a rush of capital to the same fund. Indeed, increased disclosure of endowment holdings as a response to demands by activist students (often on ethical grounds), would be likely to intensify the problem of imitative investment. Fund managers for private equity and other alternative assets, who are of course aware of these dynamics, have been able to use the increased demand for their funds as way to increase their own returns (Buckman, 2007), which tends to reduce the returns that endowments and imitative investors can receive.

In short, while we document a period of remarkable success for endowment investments, much remains to be understood about the sources of their performance, whether they can continue to succeed, and whether the approaches of the successful endowment managers can be generalized to the broader investment community. 


\section{Acknowledgements}

We thank Harvard Business School's Division of Research for financial support. We appreciate the help of the College Board and NACUBO (especially Jessica Shedd and Matthew Hamill) with data issues; and a number of individuals who served as informal advisors to us when planning this project (especially Elizabeth Huidekoper, Jay Light, Philip Rotner, and David Swensen). Excellent research assistance was provided by Yeguang Chi, Lee Gao, Susanna Kim, Timo Somervuo, Yu-Ann Wang, and especially Geraldine Kim. The editors provided helpful comments. All errors and omissions are our own. 


\section{References}

Advisory Committee on Endowment Management, 1969, Managing Educational Endowments: Report to the Ford Foundation, New York, Ford Foundation.

Brown, Keith C., Lorenzo Garlappi, and Cristian Ioan Tiu, 2007, “The Troves of Academe: Asset Allocation, Risk Budgeting, and the Investment Performance of University Endowment Funds,” Unpublished working paper, University of Texas at Austin and SUNY at Buffalo.

Buckman, Rebecca, 2007, "Venture Firms vs. Investors: Yale and the Like Quietly Cite Pressure to Back Offbeat Funds," Wall Street Journal, (August 28), C1ff.

Carlson, Scott, 2007, “A House Divided,” Chronicle of Higher Education, 53 (June 29), A20A22.

Farrell, Elizabeth, 2007, “Is Bigger Any Better?,” Chronicle of Higher Education, 54 (November 23), A23-A24.

Gompers, Paul and Josh Lerner, 2000. "Money Chasing Deals? The Impact of Fund Inflows on Private Equity Valuation," Journal of Financial Economics, 55, 281-325.

Grant, Peter, and Rebecca Buckman, 2006, “Fatter Pay Lures University Endowment Chiefs: Stanford Loses Fund Manager; McCaffery Leaves for Start-Up with Paul Allen,” Wall Street Journal, (June 27), C1ff.

Hoover, Eric, 2007, “Harvard’s New Aid Policy Raises Stakes,” Chronicle of Higher Education, 54 (December 21), A4.

Kaplan, Steven N., and Antoinette Schoar, 2005, "Private Equity Performance: Returns, Persistence and Capital Flows,” Journal of Finance, 60, 1791-1823.

Karmin, Craig, and Gergory Zuckerman, 2007, "Why Harvard is Smarting,” Wall Street Journal (August 1), C1ff.

Lerner, Josh, 2007, “Yale University Investments Office: August 2006,” Harvard Business School Case no. 9-807-073.

Lerner, Josh, Antoinette Schoar, and Wan Wongsunwai, 2007, "Smart Institutions, Foolish Choices? The Limited Partner Performance Puzzle, Journal of Finance, 62, 731-764.

Ljungqvist, Alexander, Matthew P. Richardson, and Daniel Wolfenzon, 2007, "The Investment Behavior of Buyout Funds: Theory and Evidence," ECGI - Finance Working Paper No. $174 / 2007$. 
“Manifold Effects of Hard Times,” 1974, Time Magazine, 104 (December 4).

Sender, Henny, 2007, "How a Gulf Petro-State Invests its Oil Riches,” Wall Street Journal, (August 24), A1ff.

Seward, Zachary M., 2005, "Harvard's Billion-Dollar Man Departs," http://www.forbes.com/2005/06/29/harvard-management-meyer-cx_zs_0629harvard1.html.

Shea, Christopher, 1995, “At U. of Rochester, Bad Times Prompt Bold Measures” The Chronicle of Higher Education, 42 (December 15), A33ff.

Yale University Investment Office, 2006, The Yale Endowment-2005, New Haven, Yale University. 
Table 1

\section{Descriptive statistics}

\begin{tabular}{|c|c|c|c|c|c|}
\hline \multirow[b]{2}{*}{ All } & \multicolumn{2}{|c|}{1993} & \multicolumn{2}{|c|}{2005} & \multirow{2}{*}{$\begin{array}{l}\text { Median } \\
\text { Growth }\end{array}$} \\
\hline & Median & \# schools & Median & \# schools & \\
\hline Endowment size (\$mil) & 60 & 533 & 72 & 726 & $7.4 \%$ \\
\hline$\%$ endowment return & $13.2 \%$ & 486 & $9.0 \%$ & 707 & \\
\hline$\%$ alternative allocation & $4.8 \%$ & 50 & $7.6 \%$ & 712 & $23.8 \%$ \\
\hline$\%$ equity allocation & $60.1 \%$ & 58 & $59.6 \%$ & 719 & $-1.4 \%$ \\
\hline$\%$ fixed income allocation & $31.5 \%$ & 52 & $20.4 \%$ & 719 & $-3.1 \%$ \\
\hline Spending rate & $5.0 \%$ & 350 & $4.9 \%$ & 681 & $0.3 \%$ \\
\hline Total students & 2271 & 875 & 2283 & 879 & $0.6 \%$ \\
\hline SAT math 75th percentile & 590 & 555 & 620 & 563 & $0.4 \%$ \\
\hline Tuition (\$) & 11,556 & 643 & 16,490 & 879 & $2.7 \%$ \\
\hline \multicolumn{6}{|l|}{ Ivy League } \\
\hline Endowment size (\$mil) & 2,040 & 8 & 4,780 & 8 & $8.6 \%$ \\
\hline$\%$ alternative allocation & $17.6 \%$ & 5 & $37.1 \%$ & 6 & $23.0 \%$ \\
\hline$\%$ equity allocation & $52.9 \%$ & 5 & $38.1 \%$ & 6 & $-2.3 \%$ \\
\hline$\%$ fixed income allocation & $27.8 \%$ & 5 & $13.0 \%$ & 6 & $-1.4 \%$ \\
\hline Spending rate & $4.6 \%$ & 7 & $4.6 \%$ & 6 & $0.6 \%$ \\
\hline Total students & 5600 & 8 & 5510 & 8 & $0.3 \%$ \\
\hline SAT math 75th percentile & 735 & 8 & 760 & 7 & $0.4 \%$ \\
\hline Tuition (\$) & 24,023 & 6 & 29,995 & 8 & $1.8 \%$ \\
\hline \multicolumn{6}{|l|}{ Public } \\
\hline Endowment size (\$mil) & 50 & 129 & 66 & 187 & $10.6 \%$ \\
\hline$\%$ alternative allocation & $2.9 \%$ & 10 & $5.2 \%$ & 185 & $22.0 \%$ \\
\hline$\%$ equity allocation & $61.4 \%$ & 12 & $60.5 \%$ & 187 & $-1.2 \%$ \\
\hline$\%$ fixed income allocation & $33.6 \%$ & 11 & $22.1 \%$ & 187 & $-3.6 \%$ \\
\hline Spending rate & $5.0 \%$ & 79 & $4.4 \%$ & 174 & $-0.2 \%$ \\
\hline Total students & 9800 & 272 & 9280 & 272 & $0.4 \%$ \\
\hline SAT math 75th percentile & 580 & 119 & 610 & 136 & $10.6 \%$ \\
\hline Tuition (\$) & 2,343 & 208 & 3,591 & 272 & $3.8 \%$ \\
\hline \multicolumn{6}{|l|}{ Private } \\
\hline Endowment size (\$mil) & 60 & 353 & 72 & 471 & $6.3 \%$ \\
\hline$\%$ alternative allocation & $5.3 \%$ & 32 & $9.0 \%$ & 461 & $26.0 \%$ \\
\hline$\%$ equity allocation & $59.8 \%$ & 38 & $59.5 \%$ & 466 & $-1.6 \%$ \\
\hline$\%$ fixed income allocation & $31.7 \%$ & 34 & $19.5 \%$ & 466 & $-2.3 \%$ \\
\hline Spending rate & $5.0 \%$ & 231 & $5.0 \%$ & 447 & $0.5 \%$ \\
\hline Total students & 1590 & 595 & 1740 & 595 & $0.8 \%$ \\
\hline SAT math 75th percentile & 590 & 428 & 620 & 420 & $6.3 \%$ \\
\hline Tuition (\$) & 14,331 & 429 & 19,600 & 595 & $2.5 \%$ \\
\hline
\end{tabular}

Sources: National Association of College and University Business Officers (NACUBO) and the College Board. Note: $\quad$ Statistics are presented for all schools and three subsamples: the Ivy League (Harvard, Yale, Princeton, University of Pennsylvania, Columbia, Dartmouth, Brown, and Cornell), public schools, and private schools (excluding the Ivy League). Allocations to equities, fixed income, and alternative investments are in percentages of the total market value of the endowment. The columns under "\# schools" show the number of schools for which the data are available in each year. The "median growth" column shows median values in each subsample for the mean annual growth rate of each variable from 1993 to 2005 for schools with data available in all years. Dollar values are adjusted to 2005 values and returns are deflated using the Consumer Price Index. 
Table 2

Twenty largest university endowments by total market value in 2005

$\begin{array}{lrrrr} & \begin{array}{r}\text { Endowment } \\ \text { value } 2005\end{array} & \begin{array}{r}\text { Return } \\ (\$ \mathrm{bil})\end{array} & \begin{array}{r}\text { Endowment } \\ \text { value } 1992\end{array} & \begin{array}{r}\text { Annual } \\ \text { Growth: }\end{array} \\ & 25.47 & 16.2 \% & (\$ \mathrm{bil}) & 1992-2005 \\ \text { Harvard University } & 15.22 & 19.3 \% & 3.95 & 9.7 \% \\ \text { Yale University } & 12.40 & 16.6 \% & 2.84 & 10.9 \% \\ \text { Stanford University } & 10.72 & 14.1 \% & 3.91 & 8.0 \% \\ \text { Princeton University } & 6.71 & 14.7 \% & 2.13 & 9.2 \% \\ \text { Massachusetts Institute of Technology } & 5.04 & 7.6 \% & 2.03 & 7.2 \% \\ \text { University of California } & 4.96 & 14.8 \% & 2.06 & 7.0 \% \\ \text { The Texas A\&M University System } & 4.93 & 7.0 \% & 0.84 & 14.5 \% \\ \text { University of Michigan } & 4.93 & 16.2 \% & 2.09 & 6.8 \% \\ \text { Columbia University } & 4.79 & 10.8 \% & 1.30 & 10.5 \% \\ \text { University of Texas System } & 4.38 & 4.2 \% & 2.30 & 5.1 \% \\ \text { Emory University } & 4.37 & 5.8 \% & 1.21 & 10.4 \% \\ \text { University of Pennsylvania } & 4.25 & 7.4 \% & 1.75 & 7.0 \% \\ \text { Washington University } & 4.22 & 12.3 \% & 1.47 & 8.4 \% \\ \text { Northwestern University } & 4.14 & 15.2 \% & 1.54 & 7.9 \% \\ \text { University of Chicago } & 3.83 & 15.2 \% & 0.88 & 11.9 \% \\ \text { Duke University } & 3.78 & 10.8 \% & 1.43 & 7.8 \% \\ \text { Cornell University } & 3.65 & 16.1 \% & 0.96 & 10.8 \% \\ \text { University of Notre Dame } & 3.61 & 10.8 \% & 1.74 & 5.8 \% \\ \text { Rice University } & 3.22 & 11.5 \% & 0.61 & 13.6 \% \\ \text { University of Virginia } & & & & \end{array}$

Source: National Association of College and University Business Officers (NACUBO).

Notes: The first column shows endowment values at the end of fiscal year 2005. The second column displays real investment returns net of fees in the 2004-2005 fiscal year for the total endowment. The third column shows the market values of these endowments at the end of the 1992 fiscal year adjusted for inflation, and last column shows the annualized real growth rate between 1992 and 2005. 
Figure 1

Excess returns by school type

(endowment return minus the Standard \& Poor's 500 return in same year)

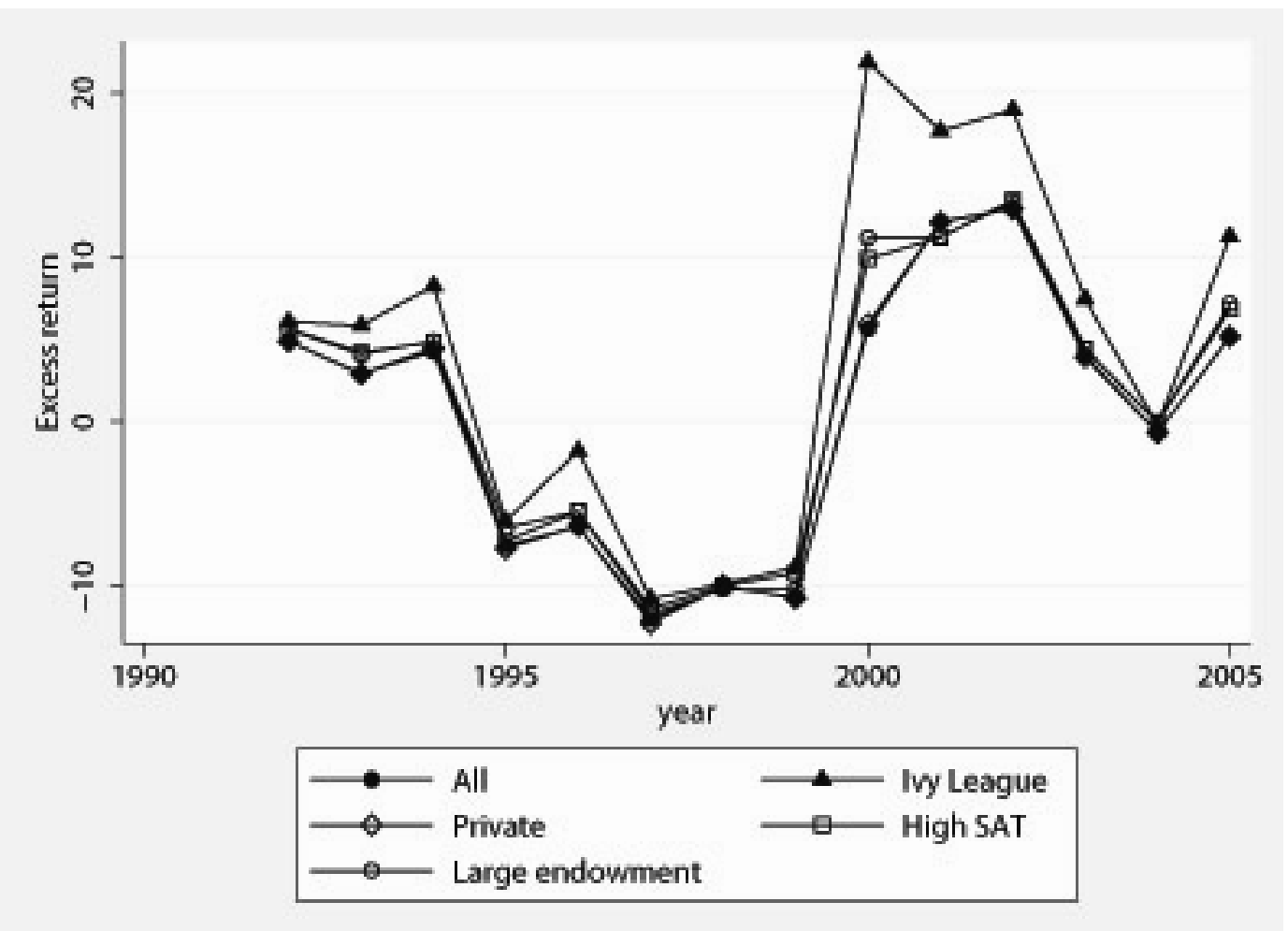

Source: National Association of College and University Business Officers (NACUBO).

Note: Median excess returns are shown for schools in each category which reported at least 10 years of return data between 1992 and 2005. "Large endowment" denotes schools in the top quartile of endowment size in 1992, and "High SAT" denotes schools in the top quartile of SAT score in the sample in 1992. The "Private" "Large endowment" and "High SAT" categories exclude schools in the Ivy League. 
Figure 2

Asset allocation by year

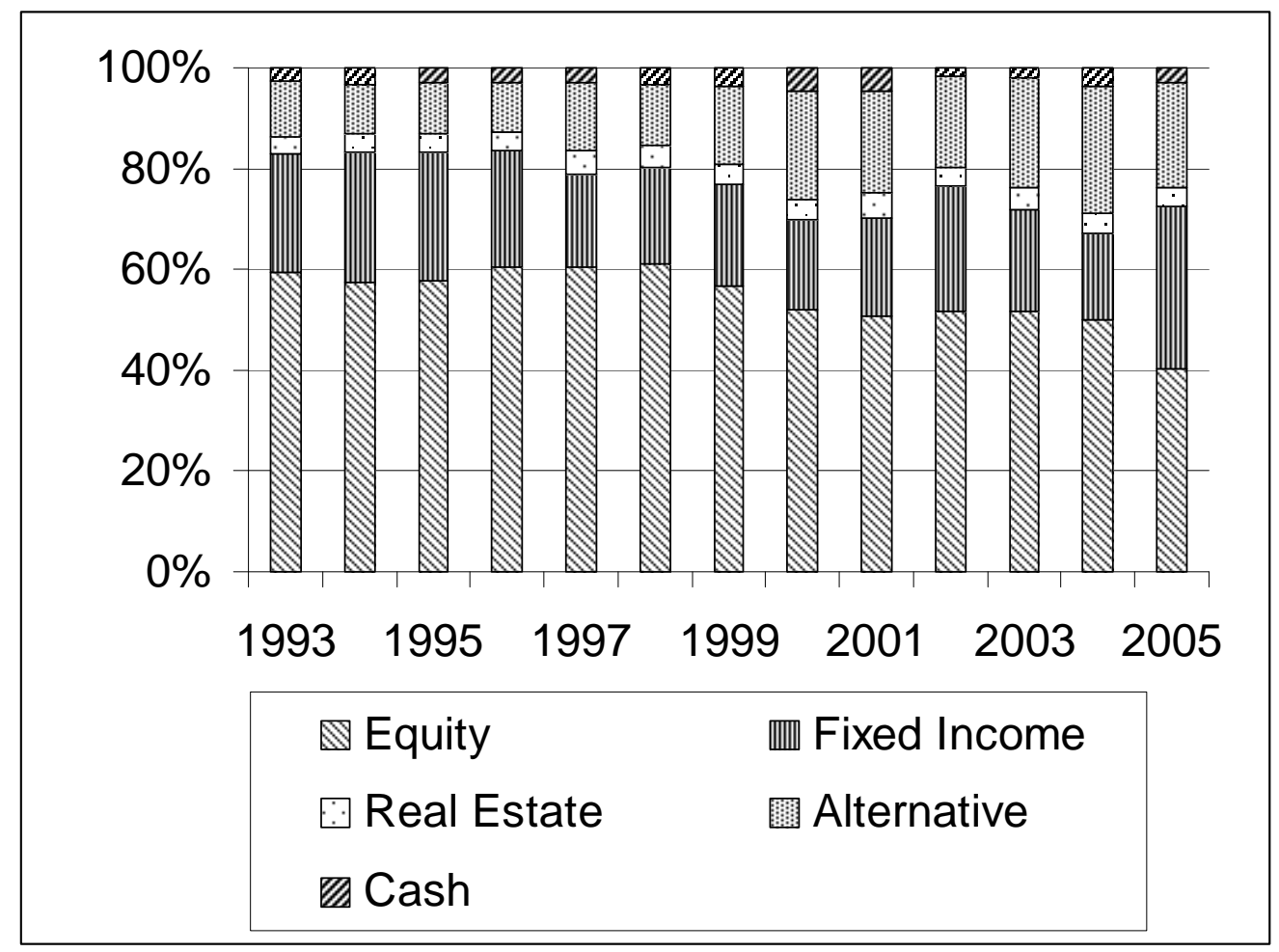

Source: National Association of College and University Business Officers (NACUBO). Note: $\quad$ Asset values for each asset class are aggregated across all schools with at least 10 years of data between 1993 and 2005 and which report asset values for all five asset classes. 
Figure 3

Alternative asset allocation by school type and year (median fraction of total assets invested in alternative asset classes, including hedge funds, venture capital, and private equity)

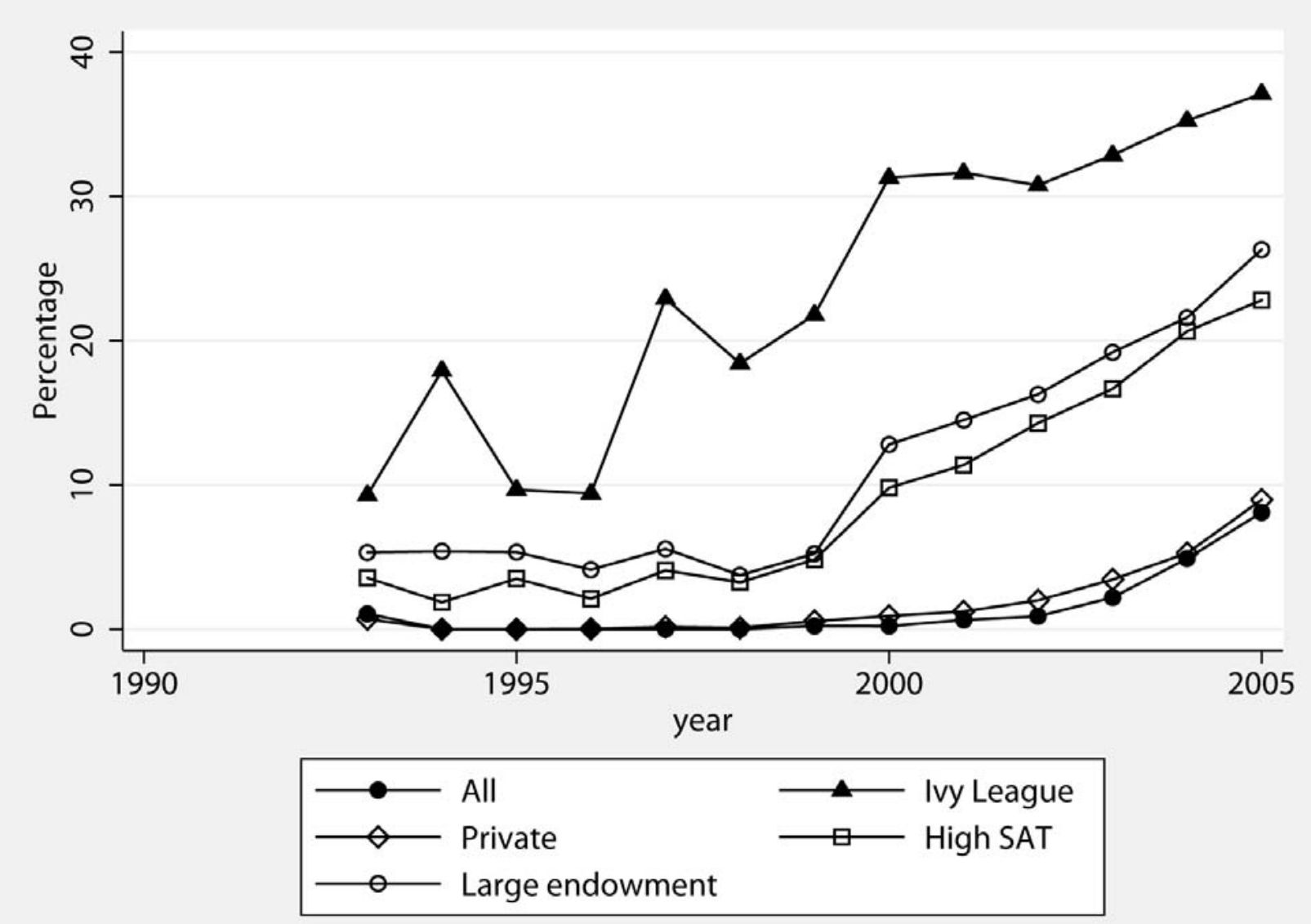

Source: National Association of College and University Business Officers (NACUBO).

Note: Based on data for schools which reported at least 10 years of return data between 1992 and 2005. "Large endowment" denotes schools in the top quartile of endowment size in 1992, and "High SAT" denotes schools in the top quartile of SAT score in the sample in 1992. The "Private", "Large endowment", and "High SAT" categories exclude schools in the Ivy League. 
Table 3

Return decomposition

\begin{tabular}{c|rrrrrrrrrr}
\multirow{2}{*}{ Year } & \multicolumn{1}{|c}{ All } & \multicolumn{1}{c}{ Ivy League } & \multicolumn{1}{c}{ Private } & \multicolumn{2}{c}{ Large } \\
& endowment & \multicolumn{2}{c}{ High SAT } \\
& Return & Bench & Return & Bench & Return & Bench & Return & Bench & Return & Bench \\
\hline 1994 & 5.8 & -1.1 & 8.5 & -0.1 & 3.4 & -2.1 & 3.3 & -1.9 & 3.3 & -2.0 \\
1995 & 16.1 & 16.2 & 16.4 & 17.2 & 16.0 & 16.2 & 16.5 & 16.5 & 16.0 & 16.2 \\
1996 & 19.7 & 16.6 & 24.4 & 19.6 & 18.7 & 16.5 & 18.9 & 16.7 & 19.1 & 16.8 \\
1997 & 21.5 & 21.4 & 24.6 & 21.4 & 20.7 & 22.0 & 20.8 & 22.2 & 20.4 & 21.6 \\
1998 & 18.6 & 20.9 & 19.1 & 21.0 & 18.8 & 21.2 & 18.5 & 21.3 & 18.7 & 21.1 \\
1999 & 10.4 & 15.8 & 11.9 & 16.2 & 9.7 & 16.1 & 10.0 & 16.3 & 10.3 & 16.4 \\
2000 & 20.2 & 15.9 & 26.8 & 24.1 & 18.5 & 14.2 & 21.0 & 16.0 & 21.9 & 16.8 \\
2001 & -2.9 & -8.9 & 2.4 & -7.3 & -4.2 & -9.5 & -4.7 & -9.5 & -4.6 & -9.5 \\
2002 & -4.5 & -12.1 & -0.8 & -11.5 & -5.4 & -12.4 & -5.4 & -12.4 & -5.2 & -12.4 \\
2003 & 4.6 & 0.2 & 9.1 & 0.2 & 3.7 & 0.2 & 3.3 & 0.0 & 3.3 & -0.1 \\
2004 & 17.3 & 11.3 & 19.5 & 10.0 & 16.6 & 11.9 & 17.2 & 11.6 & 17.1 & 11.6 \\
2005 & 13.1 & 6.1 & 16.9 & 6.9 & 12.2 & 6.1 & 13.0 & 6.3 & 13.5 & 6.6 \\
\hline Mean & $11.7 \%$ & $8.5 \%$ & $14.9 \%$ & $9.8 \%$ & $10.7 \%$ & $8.4 \%$ & $11.0 \%$ & $8.6 \%$ & $11.1 \%$ & $8.6 \%$
\end{tabular}

Sources: Endowment returns are from the National Association of College and University Business Officers (NACUBO). The benchmark returns for equities, fixed income, real estate, and cash are the annual yields from the Standard \& Poor's 500, the Lehman US Aggregate bond index, the Case-Shiller index, and the three-month treasury rate, respectively. The benchmark returns for alternative assets are equalweighted averages of the one-year returns for private equity and venture capital investments reported in the VentureXpert database and hedge fund returns as reported in the Hennessee Hedge Fund Index.

Notes: Based on data for schools which reported at least 10 years of total return data. Total endowment returns and benchmark returns are presented for six samples of schools. "Large endowment" denotes schools in the top quartile of endowment size in 1992, and "High SAT" denotes schools in the top quartile of SAT score in the sample in 1992. The "Private", "Large endowment", and "High SAT" categories exclude schools in the Ivy League. For each subset "Return" indicates the value-weighted average endowment return, and "Bench" indicates benchmark returns calculated from allocations of each group of endowments to five asset classes: equities, fixed income, real estate, alternatives, and other. The benchmark return is calculated as the average return of asset class indices weighted by the percentage of total assets allocated at the end of the previous fiscal year to each asset class. 